\title{
Study about the Physical Properties of Sugarcane Crop in Kawardha (Kabirdham) District, Chhattisgarh, India
}

\author{
Tahsin Ashraf ${ }^{1 *}$, R. K. Naik ${ }^{1}$ and D. K. Roy ${ }^{2}$ \\ ${ }^{1}$ Department of Farm Machinery and Power Engineering, IGKV, Raipur, Chhattisgarh, India \\ ${ }^{2}$ Department of Farm Machinery and Power Engineering, SK CARS, IGKV, Raipur, \\ Chhattisgarh, India \\ *Corresponding author
}

\section{A B S T R A C T}

\begin{tabular}{|l|}
\hline Ke y w o r d s \\
$\begin{array}{l}\text { Sugarcane crop, } \\
\text { Length, Diameter } \\
\text { and Node distance }\end{array}$ \\
\hline Article Info \\
\hline $\begin{array}{l}\text { Accepted: } \\
\text { 20 August } 2020 \\
\text { Available Online: } \\
\text { 10 September } 2020\end{array}$ \\
\hline
\end{tabular}

Sugarcane, (Saccharum officinarum) L., is one of the several species of tall perennial true grasses of the genus Saccharum. Sugarcane is the source of sugar in all tropical and subtropical countries of the world that belongs to family Poaceae. The various physical parameters of sugarcane crops such as Length, diameter of cane and node distance, were studied in Kawardha district, (C.G.). Different varieties of sugarcane were available in Kawardha District (C.G.) such as Co-80036, Co-86032, COVSI-9805, Co-8014 and COM-0265. It was found that sugarcane length: 2000 to $3000 \mathrm{~mm}$, diameter: 30 to $50 \mathrm{~mm}$. The parameters depend on their variety, soil and climatic condition.

\section{Introduction}

India is the second-largest producer of sugarcane in the world and Brazil in first position. Sugarcane is an important commercial crop (industrial crop), with acreage of about 4 million hectares and production of 300 million tonnes in India. In India's sugar production increased to $11.5 \%$ during 2014-15, season on bumper cane production, the world sugar production amounted to approximately 175.1 million metric tons. Asia was the largest sugarproducing region in the world, yielding approximately 66.12 million metric tons of sugar. India, China and Thailand where the region's top sugar producers (www.businessstandard.com). Physical parameters such as length and diameter of millable cane, node characteristics, leaf characteristics and amount of trash for the major varieties of sugarcane are measured in the farmers' field at Kawardha district, Variety is given as - Co80036. Blackburn (1984) describes sugarcane as a tall tropical grass with a single unbranched stem of average height in the range of 3 to $4 \mathrm{~m}$ with a stem diameter ranges from 3 to $5 \mathrm{~cm}$ depending on the species. Bull (2000) reported that inter node length can reach over $30 \mathrm{~cm}$, depending on growth conditions, and 
stems normally reach two to three metres in the normal growing season.

\section{Materials and Methods}

The various physical parameters such as length and diameter of millable cane, node distance, row to row and plant to plant for the different varieties (Such as Co-80036, Co86032, COVSI-9805, Co-8014 and COM0265.) of sugarcane are measured in the farmers' field in Kawardha (Kabirdham) district,(C.G.)

\section{Length of the sugarcane}

The millable cane length in the farmers' field is measured using a $3 \mathrm{~m}$ measuring tape and is recorded. Matured cane lengths were measured of different variety in the field. Sugarcane variety in Chhattisgarh are Co80036, CO-86032, COVSI-9805, CO-8014 and $\mathrm{COM}-0265$.

\section{Diameter of the cane}

The diameter of the matured sugarcane was observed in the different varieties. The diameter of the sugarcanes was measured at three different positions viz., top, middle and bottom. The diameter varied from top to bottom and the variations depended upon the soil type and the climatic conditions prevailing in the growth phase of the sugarcane. From the data, it is clear that the crop growth is less in the dry land conditions than the wet land conditions and irrigated conditions. The diameter of cane varieties of Co-80036, Co-86032, COVSI-9805, CO-8014 and $\mathrm{COM}-0265$.

\section{Results and Discussion}

Physical properties of sugarcane crop at the time of harvest were studied for the harvesting. The various physical parameters such as length, diameter of cane, cane, row to row and plant to plant distance were studied in Kawardha (Kabirdham) district, (C.G.).

\section{Length of the sugarcane}

The lengths of sugarcane, five different verities of sugarcane locally grown in the Kawardha district were measured from the field (Table 1).

It was observed that average length of sugarcane varieties was found to be Co80036, Co-86032, COVSI-9805, Co-8014 and COM-0265 was 206, 159.7, 174.4176 and $202.2 \mathrm{~cm}$ respectively. The range of the millable cane variety of Co-86032 was found to be $132 \mathrm{~cm}$ to $200 \mathrm{~cm}$ which was lowest and 140 to 300 was highest among observed varieties.

\section{Diameter of the cane}

The diameter of sugarcane of different varieties, 5 verities were measured from the field and interpreted in the Table 2.

The diameter of sugarcane of different varieties, 5 verities were measured from the field and interpreted in the Table 2 It was observed that average maximum and minimum diameter of sugarcane variety was found to be Co-86032 (top, middle and bottom diameter of sugarcane was found that the, 2.85, 3.15 and 3.38 respectively.) and Co80036 (top, middle and bottom diameter of sugarcane was found that the, 2.63, 2.81 and 3.10respectively), respectively. The range of the sugarcane diameter variety of Co-86032 was found to be top, middle and bottom diameter of sugarcane was 2.2 to $3.5,2.5$ to 3.91 and 2.7 to 4.13 respectively, which was highest and the top, middle and bottom diameter of sugarcane was found the 2.16 3.34, 2.3 - 3.5 and 2.54-3.18 respectively, was lowest among observed varieties Co-80036. 
Table.1 Length of different variety of sugarcane crop

\begin{tabular}{|c|c|c|c|c|c|}
\hline Variety & Co-80036 & Co-86032 & COVS I-9805 & Co-8014 & COM-0265 \\
\hline length, cm & 206.0 & 159.7 & 176.4 & 176.0 & 222.2 \\
\hline Range, cm & $140-300$ & $132-200$ & $150-205$ & $140-210$ & $168-280$ \\
\hline S.D. & 55.16 & 20.16 & 19.35 & 29.03 & 49.99 \\
\hline
\end{tabular}

Table.2 Diameter, $\mathrm{cm}$ of different variety of sugarcane crop

\begin{tabular}{|c|c|c|c|c|}
\hline Variety & Particular & $\begin{array}{c}\text { Average } \\
\text { diameter, } \mathrm{cm}\end{array}$ & Range, cm & S.D. $(\sigma)$ \\
\hline \multirow[t]{3}{*}{ Co-80036 } & Top & 2.632 & 2.16 to 3.34 & 0.472 \\
\hline & Middle & 2.811 & 2.3 to 3.5 & 0.462 \\
\hline & Bottom & 3.103 & 2.54 to 3.18 & 0.483 \\
\hline \multirow[t]{3}{*}{ Co-86032 } & Top & 2.854 & 2.2 to 3.5 & 0.519 \\
\hline & Middle & 3.15 & 2.5 to 3.91 & 0.533 \\
\hline & Bottom & 3.38 & 2.7 to 4.13 & 0.509 \\
\hline \multirow{3}{*}{ COVSI-9805 } & Top & 2.613 & 2.0 to 3.2 & 0.421 \\
\hline & Middle & 3.091 & 2.5 to 3.82 & 0.483 \\
\hline & Bottom & 3.28 & 2.76 to 3.97 & 0.470 \\
\hline \multirow[t]{3}{*}{ Co-8014 } & Top & 2.931 & 2.21 to 3.81 & 0.606 \\
\hline & Middle & 3.40 & 2.40 to 4.29 & 0.470 \\
\hline & Bottom & 2.98 & 2.20 to 3.66 & 0.586 \\
\hline \multirow[t]{3}{*}{ COM-0265 } & Top & 2.88 & $2.3-3.43$ & 0.457 \\
\hline & Middle & 3.13 & 2.5 to 3.8 & 0.485 \\
\hline & Bottom & 3.3 & 2.7 to 3.84 & 0.488 \\
\hline
\end{tabular}

Table.3 Different morphometric properties of sugarcane crop

\begin{tabular}{|c|c|c|c|c|}
\hline Variety & Particular & Average, cm & Range, cm & S.D. $(\sigma)$ \\
\hline \multirow[t]{3}{*}{ Co-80036 } & Node distance, $\mathrm{T}$ & 14.54 & 12.5 to 16.3 & 1.1946 \\
\hline & Node distance, $\mathrm{M}$ & 15.56 & 13.9 to17 & 1.1027 \\
\hline & Node distance, B & 8.47 & 7 to 10 & 0.861 \\
\hline \multirow[t]{3}{*}{ Co-86032 } & Node distance, $\mathrm{T}$ & 10.46 & 9 to 12 & 1.152 \\
\hline & Node distance, $\mathrm{M}$ & 9.88 & 8 to 12 & 1.342 \\
\hline & Node distance, B & 6.80 & 5 to 7.52 & 0.955 \\
\hline \multirow[t]{3}{*}{ COVSI-9805 } & Node distance, $\mathrm{T}$ & 8.42 & 7 to 10 & 0.937 \\
\hline & Node distance, $\mathrm{M}$ & 12.51 & 11 to 2.5 & 1.018 \\
\hline & Node distance, B & 5.85 & 4.9 to 7 & 0.59 \\
\hline \multirow[t]{3}{*}{ Co-8014 } & Node distance, $\mathrm{T}$ & 11.84 & 11 to13 & 0.52 \\
\hline & Node distance, $\mathrm{M}$ & 10.32 & 9 to 13 & 1.25 \\
\hline & Node distance, B & 6.77 & 5to 8 & 0.96 \\
\hline \multirow[t]{3}{*}{ Co-0265 } & Node distance, $\mathrm{T}$ & 9.51 & 8 to 11.2 & 1.09 \\
\hline & Node distance, $\mathrm{M}$ & 12.14 & 10 to 13.5 & 1.28 \\
\hline & Node distance, B & 7.74 & 5 to 11 & 1.84 \\
\hline
\end{tabular}


The variations in Co-86032 for stem was observed highest $(\sigma: 0.519,0.533$ and 0.509 was found the top, middle and bottom diameter of sugarcane respectively), whereas it was lowest in case of Co-80036. ( $\sigma: 0.472,0.462$ and 0.483 was found the top, middle and bottom diameter of sugarcane respectively).

\section{Different variety of morphological characteristics of sugar cane crop}

The node distance of sugarcane of five different varieties were measured from the field and interpreted in the Table 3.

It was observed that average maximum and minimum node distance of sugarcane variety was found to be Co-80036 (top, middle and bottom node distance of sugarcane was found that the, 14.54, 15.56 and 8.47 respectively.) and Co-86032 (top, middle and bottom node distance of sugarcane was found that the, 10.46, 9.88and 6.80respectively), respectively. The range of the sugarcane node distance variety of Co-86032 was found to be top, middle and bottom, node distance of sugarcane was 12.5 to $16.3,13.9$ to 17 and 7 to 10 respectively, which was highest and the top, middle and bottom node distance of sugarcane was found the 7 to 10,11 to 12.5 and 4.9 to 7 respectively, was lowest among observed varieties COVSI-9805. The variations in COM-0265 for node distance were observed highest COM-0265. ( $\sigma: 1.08$, 1.282 and 1 was found the top, middle and bottom node distance of sugarcane respectively), whereas it was lowest in case of CO-8014( $\sigma$ : $0.521,1.25$ and 0.963 was found the top, middle and bottom node distance of sugarcane respectively).

In conclusion this study was understood the physical properties of sugarcane crop. The various physical parameters such as length, diameter and nodal distance were studied in Kawardha district, (C.G).The length of the sugarcane varieties such as Co-80036, Co86032, COVSI-9805, Co-8014 and COM-0265 was 206, 159.7, 174.4176 and $202.2 \mathrm{~cm}$ respectively. The maximum and minimum diameters such as Co-80036 -cm, Co-86032, COVSI-9805, Co-8014 and COM-0265 were 2.54 to $3.18,2.7$ to $4.13,2.76$ to $3.97,2.22$ to 3.66 and 2.7 to 3.84 respectively.

\section{References}

Anonymous. 2010. Crop growing manual of sugarcane. Netafim ACS, Israel. http:// www.sugarcanecrops.com

Thotad and Kiran, P. 2013. Design and fabrication of small scale sugarcane harvesting machine., 2(3): 2278-0149

Bastian, J. and Shridar, B. 2014. Physical properties of sugarcane pertaining to the design of a whole stalk sugarcane harvester. International journal of engineering sciences and research Technology., 3(11): 2277-9655

Blackburn, F. 1984. Sugar-cane. Longman Group Limited, Essex, UK

Bull, T. 2000. The Sugarcane Plant, manual of cane growing. Bureau of Sugar Experimental Stations, Indooroopilly, Australia., (4): 71-83.

Miller, J. D. and R. A. Gilbert. 2009. Sugarcane Botany- A Brief View. Agronomy Department, Florida Cooperative Extension Service, Institute of Food and Agricultural Sciences, SSAGR., 234.

Beckwith, C. A. 1995. Whole stalk sugar cane harvester that tops, cuts, cleans and loads. U.S. Patent No. 5, 463, 856.

Gupta, C. and Oduori, M. 1992. Design of the revolving knife-type sugarcane base cutter. ASAE., 35(6): 1747-1752.

\section{How to cite this article:}

Tahsin Ashraf, R. K. Naik and Roy, D. K. 2020. Study about the Physical Properties of Sugarcane Crop in Kawardha (Kabirdham) District, Chhattisgarh, India. Int.J.Curr.Microbiol.App.Sci. 9(09): 3001-3004. doi: https://doi.org/10.20546/ijcmas.2020.909.370 